University of Nebraska - Lincoln

DigitalCommons@University of Nebraska - Lincoln

Reconstruction of Hydrological Changes and Response to Effective Moisture Variations from North-Central USA Lake Sediments

Antje Schwalb

GeoForschungsZentrum Potsdam, PB 3.3, Telegrafenberg, D-14473 Potsdam, Germany

Walter E. Dean

U.S. Geological Survey, Denver, CO, dean@usgs.gov

Follow this and additional works at: https://digitalcommons.unl.edu/usgsstaffpub

Part of the Earth Sciences Commons

Schwalb, Antje and Dean, Walter E., "Reconstruction of Hydrological Changes and Response to Effective Moisture Variations from North-Central USA Lake Sediments" (2002). USGS Staff -- Published Research. 322.

https://digitalcommons.unl.edu/usgsstaffpub/322

This Article is brought to you for free and open access by the US Geological Survey at DigitalCommons@University of Nebraska - Lincoln. It has been accepted for inclusion in USGS Staff -- Published Research by an authorized administrator of DigitalCommons@University of Nebraska - Lincoln. 


\title{
Reconstruction of hydrological changes and response to effective moisture variations from North-Central USA lake sediments
}

\author{
Antje Schwalb $^{\mathrm{a}, *}$, Walter E. Dean ${ }^{\mathrm{b}}$ \\ ${ }^{a}$ GeoForschungsZentrum Potsdam, PB 3.3, Telegrafenberg, D-14473 Potsdam, Germany \\ ${ }^{\mathrm{b}}$ US Geological Survey, Box 25046, MS980 Federal Center, Denver, CO, USA
}

Received 9 November 2000; accepted 30 September 2001

\begin{abstract}
Ratios of the stable isotopes of oxygen and carbon in benthic ostracodes and marl from cores taken from two lakes in northcentral Minnesota reflect Holocene hydrological and vegetation changes. Oxygen isotopes show that Williams and Shingobee Lakes, located in the same watershed but with different positions along a hydrologic gradient, were connected before $9.8 \mathrm{ka}$ as part of a larger lake, Lake Willobee. From 9.8-7.7 ka, the level of Lake Willobee fell as a result of glacial retreat and increasing evaporation, leaving small separated basins. Further decreases in lake level after $7.7 \mathrm{ka}$ due to increasing aridity triggered the inflow of ground water in Williams Lake at about $7 \mathrm{ka}$, and in Shingobee Lake at about $5 \mathrm{ka}$. After $4 \mathrm{ka}$ effective moisture increased. The carbonisotope record reflects changes in vegetation with higher $\delta^{13} \mathrm{C}$ values during the prairie period (7.7-4 ka) and lower values during preceding and succeeding forest periods. The differences in timing of hydrological events show that the biotic and geochemical response of the lakes to climate variations is mediated by their hydrologic systems. The response may be strongly spatially heterogeneous and can result in contrasting information from geochemical and biotic proxies from the same paleorecord. (C) 2002 Elsevier Science Ltd. All rights reserved.
\end{abstract}

\section{Introduction}

The Northern Great Plains of western Minnesota and eastern North and South Dakota are located on a steep climatic gradient that reflects a triple junction of three airmasses: cold, dry polar air; dry North Pacific air; and moist, warmer air from the Gulf of Mexico and the Atlantic realm (Fig. 1A, cf. Anderson et al., 1993). This results in a $\mathrm{W}-\mathrm{E}$ trending moisture gradient (Fig. 1B) reflected in vegetation boundaries that separate prairie grassland, deciduous forest, and coniferous forest, all within a few hundred kilometers. During the midHolocene, the prairie margin first moved eastward and then westward by about $100 \mathrm{~km}$ relative to its present position (Wright, 1976). The sediments of tens of thousands of lakes have recorded the interplay of regional climate and local hydrology, making this region ideal for testing the biologic and isotopic responses to

\footnotetext{
*Corresponding author. Present address: Institut für UmweltGeochemie, Universität Heidelberg, Im Neuenheimer Feld 236, D69120 Heidelberg, Germany. Tel.: 49-6221-54-6006; fax: 49-6221-545228.

E-mail address: aschwalb@ugc.uni.heidelberg.de (A. Schwalb).
}

rapid paleoclimatological and paleohydrological changes.

Biological remains and geochemical signatures in lake sediments from the north-central USA have been used to reconstruct changes in water chemistry that have been interpreted mostly as direct responses to changes in effective moisture (see summary in Fritz, 1996; Fritz et al., 2000b). Major-ion water types can change with major variations in climate. For example, wetlands that normally contain bicarbonate water can become dominated by sulfate water during major droughts, and wetlands having sulfate water can become dominated by bicarbonate water during major wet periods (LaBaugh et al., 1996). Differences in watershed geology and topography, however, may be responsible for limnological contrasts and anomalies in adjacent lakes (Northcote and Hall, 1983). Recent interlake comparisons also show that differences among sites may be attributed to variation in local hydrology (Fritz et al., 2000a).

With the increasing number of available long paleorecords it has become apparent that lakes in the northcentral USA seem to have responded to the early Holocene increase in aridity as shown by the east- and northward expansion of prairie. Although available 

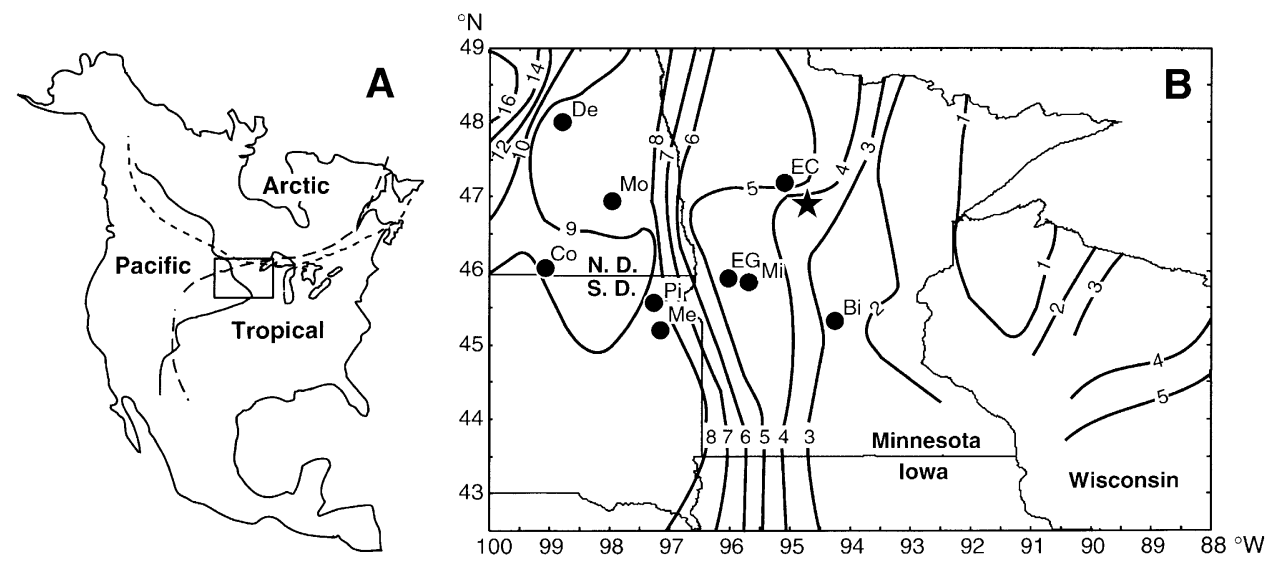

Fig. 1. Map with (A) major airstreams interacting in the in North America (modified from Bryson and Hare, 1974); (B) highly smoothed contours of total cations in milliequivalents per liter in lakes in the north-central United States (data of Gorham et al., 1983) and lake sites discussed in this paper: $\mathrm{Co}=$ Coldwater Lake, $\mathrm{De}=$ Devils Lake, $\mathrm{Mo}=$ Moon Lake, $\mathrm{Pi}=$ Pickerel Lake, $\mathrm{Me}=$ Medicine Lake, $\mathrm{EG}=\mathrm{Elk}$ Lake, Grant County, $\mathrm{EC}=\mathrm{Elk}$ Lake, Clearwater County, $\mathrm{Mi}=$ Lake Mina, star $=$ Williams and Shingobee Lakes, $\mathrm{Bi}=\mathrm{Big}$ Watab.

moisture decreases, and lake salinity increases, from east to west, there can be considerable variation in total salinity and major-ion water types that is not due to simple precipitation-evaporation gradients. The midHolocene was drier than today, although magnitude and duration of aridity varied considerably (Meltzer, 1999; Fritz et al. 2000b).

The comparison of the paleorecords from hydrologically open Shingobee Lake and hydrologically closed Williams Lake in the same watershed (Fig. 2A), will serve as a test of the extent to which any divergences between proxies are a result of evaporation, lakeground water interaction, and hydrogeological setting. We chose stable oxygen and carbon isotopes from the biogenic carbonate of ostracode valves that calcify in approximate equilibrium with the lake water (Turpen and Angell, 1971; Lister, 1988). More recently, however, culturing experiments and studies of living ostracodes and modern lake waters have shown that ostracode species calcify out of isotopic equilibrium with water. Oxygen-isotope values may display positive offsets from equilibrium of about 2\% (Xia et al., 1997a; von Grafenstein et al., 1999; Keatings, 2000). Ostracodes are also valuable environmental indicators that provide information about the physical and chemical properties of their environment (Delorme, 1969, 1970, 1991; Forester et al., 1987; Smith, 1993). Additionally, oxygen and carbon isotopes from marl were analyzed to cover gaps in the ostracode record and to compare the isotopic signatures of surface waters where marl precipitates versus bottom waters at the sediment-water interface, where the analyzed ostracodes live.

Williams and Shingobee Lakes, Minnesota, are situated in the conifer forest near the modern prairieforest border and within the Itasca-St. Croix moraine interlobate region, an area of approximately $500 \mathrm{~km}^{2}$ where two prominent end moraines merge (Norton,
1982). They were formed as blocks of buried ice melted following the abandonment of a meltwater channel. The glacial stratigraphy in the vicinity of Williams Lake consists of alternating units of sand and gravel and till. The glacial stratigraphy in the vicinity of Shingobee Lake is highly variable and consists mainly of sand and to a lesser amount of till (Winter and Rosenberry, 1997). The lakes are the sites of a long-term interdisciplinary research initiative (IRI) of the US Geological Survey (USGS), and have been monitored for the past 20 years, providing modern climatic, hydrogeologic and chemical data to aid in calibrating and understanding Holocene environmental change at the lake sites (Winter and Rosenberry, 1997). Both lakes are about $10 \mathrm{~m}$ deep, but the area of Shingobee Lake is about $67 \%$ larger, and the volume of Shingobee Lake is nearly $100 \%$ greater than those of Williams Lake. The water residence times of Williams and Shingobee Lakes are 3 years and 6 months, respectively (Winter and Rosenberry, 1997).

Streamflow dominates the hydrological fluxes to and from Shingobee Lake $(72 \%$ and $96 \%$, respectively, Rosenberry et al., 1997), whereas ground water controls the fluxes to and from Williams Lake. During a 12-years study, ground water seepage into Williams Lake accounted for $65 \%$ of the annual water input to the lake from net-flow calculations (Rosenberry et al., 1997), 53\% by solute calculations (LaBaugh et al., 1997), but only $2-3 \%$ by hydrogen- and oxygen-isotope modeling (Kendall et al., 1997); the remainder was from precipitation. Seepage from Williams Lake accounted for $75 \%$ of annual water losses from the lake; and $22 \%$ was removed by evaporation (Rosenberry et al., 1997). It is puzzling that estimates of seepage into Williams Lake determined from net-flow calculations are consistent with calculations based on solutes, but differ from estimates obtained by isotope modeling. Ground water flow into the sandy bed of Williams Lake is 


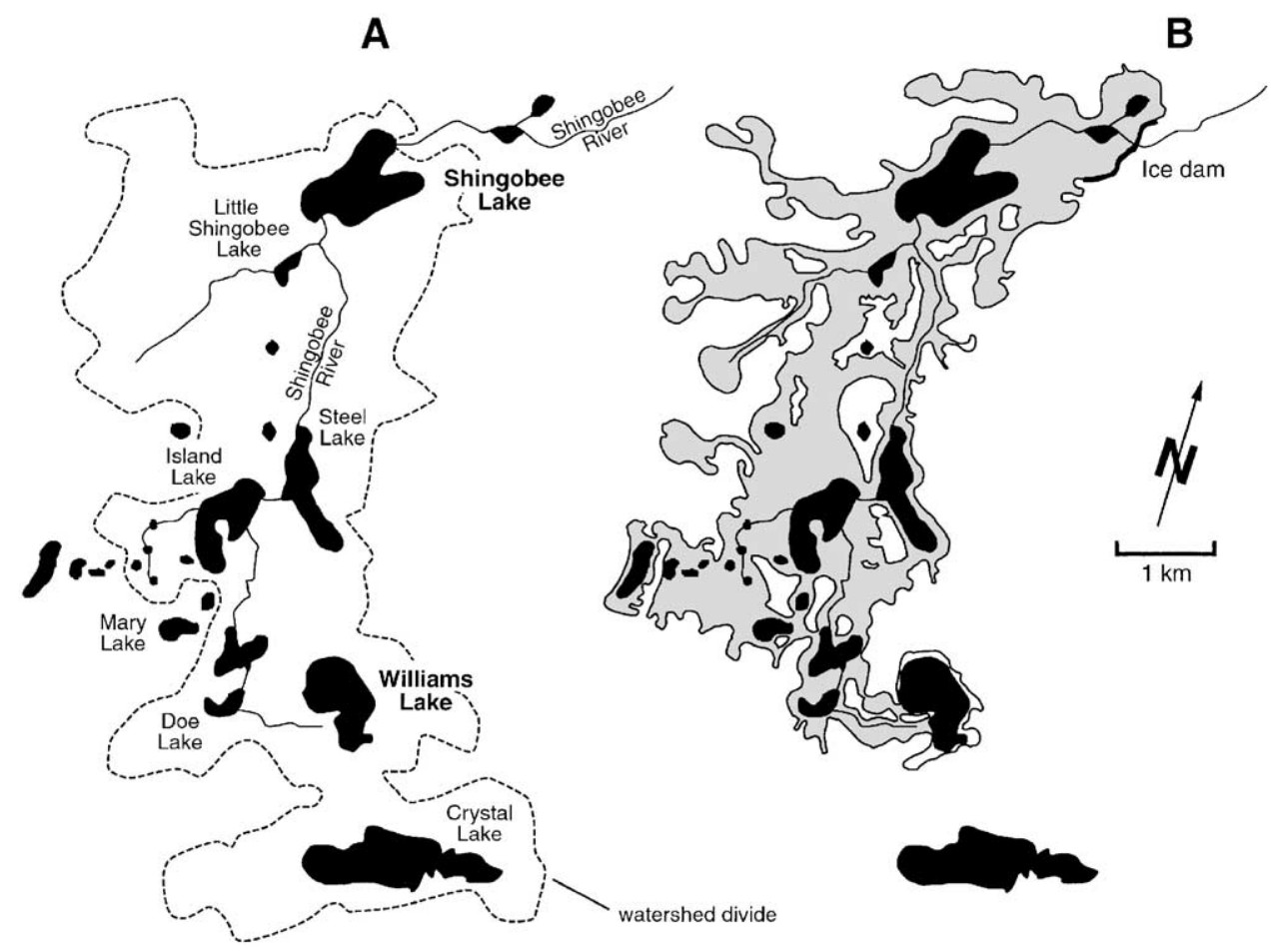

Fig. 2. Map showing the (A) Williams and Shingobee Lake watershed; and (B) lakes of the modern Shingobee watershed (black) and the extension of Glacial Lake Willobee (gray shaded).

diffuse, and in places the seepage rate decreases nearly exponentially away from the shoreline (Erickson, 1981; Rosenberry, 1985). In contrast, most ground water flow into Shingobee Lake, estimated to contribute about $24 \%$ of fluxes to the lake (Rosenberry et al., 1997), and in the Shingobee River is focused at springs in the nearshore zones and along the perimeter of the water bodies, where slightly more permeable fine sand layers within the silt intersect the lake floor and stream bed (Winter, 1999). Recent evidence indicates that there are deeper, sublacustrine springs in Shingobee Lake (Dean and Bradbury, 1997; Dean and Schwalb, in press).

\section{Methods}

A 7-m-long core was collected from Williams Lake, and a 9.3-m-long core was collected from Shingobee Lake (Locke, 1995) using a modified Livingstone piston corer $5 \mathrm{~cm}$ in diameter (Wright, 1967). Approximately 12,000 ostracode valves from 74 sub-samples were recovered from sediments by sieving $(250 \mu \mathrm{m}$ sieve). The valves were cleaned with distilled water and dried with $95 \%$ ethanol. The best preserved valves of Candona acuta and Candona ohioensis, and very few samples of Candona candida and Candona rawsoni from the Shingobee Lake core, and Candona rawsoni and a few specimens of Candona ohioensis, Candona candida and Candona sp. from the Williams Lake core were selected for analysis of ratios of the stable isotopes of oxygen and carbon. A total of 228 ostracode samples consisting of 1-6 valves of one species each was selected from 37 and 40 stratigraphic levels in the cores from Williams and Shingobee Lakes, respectively, with up to 8 replicates per level. A total of 133 marl samples was collected from 40 and 53 stratigraphic levels in the cores from Williams and Shingobee Lakes, respectively, with up to 6 replicates per level. All samples were reacted with $100 \%$ phosphoric acid in an automated Kiel carbonate extraction device, and analyzed in line with a Finnigan MAT 251 triple-collector mass spectrometer in the stable isotope laboratory, USGS, Denver, Colorado. Samples were roasted in vacuum for $1 \mathrm{~h}$ at $380 \pm 10^{\circ} \mathrm{C}$ for the removal of volatile organic carbon prior to reaction in the Kiel device. The precision of the method is $\pm 0.1 \%$ for both $\delta^{18} \mathrm{O}$ and $\delta^{13} \mathrm{C}$. The samples of pure $\mathrm{CaCO}_{3}$ reacted and analyzed ranged between 10 and $100 \mu \mathrm{g}$ in size. Results are expressed in the usual delta $(\delta)$ notation as the permil (\%) difference relative to the Vienna Pee Dee Belemnite (VPDB) marine carbonate standard for carbon and oxygen:

$\delta \%_{0}=\left[\left(R_{\text {sample }} / R_{\mathrm{VPDB}}\right)-1\right] \times 10^{3}$,

where $R$ is the ratio $\left({ }^{13} \mathrm{C}:{ }^{12} \mathrm{C}\right)$ or $\left({ }^{18} \mathrm{O}:{ }^{16} \mathrm{O}\right)$.

The chronologies for the two cores used for this study, expressed as thousands of radiocarbon years before present (ka), are based on five accelerator mass spectrometry (AMS) radiocarbon dates from the Williams Lake 
core and pollen zonation from both cores (Locke, 1995; Locke and Schwalb, 1997). The radiocarbon ages have not been calibrated to account for variations in ${ }^{14} \mathrm{C}$ production in the atmosphere in order to compare the dates at this site with the uncalibrated dates for other published sites. The pollen zonations defined for Williams and Shingobee Lakes resemble those of Whitlock et al. (1993) for Elk Lake, approximately $45 \mathrm{~km}$ northwest of Shingobee Lake and dated by varve chronology and radiocarbon (Anderson et al., 1993), and of McAndrews (1966) for Bog D and Martin Pond near Elk Lake, where the pollen zones have been dated by radiocarbon.

Five local pollen-assemblage zones were identified in the cores from Williams and Shingobee Lakes (Locke, 1995) that divide the Holocene into five periods: The spruce period $(>10-9.8 \mathrm{ka})$, the jack/red pine period $(9.8-7.7 \mathrm{ka})$, the prairie period $(7.7-4 \mathrm{ka})$, the hardwood period $(4-3.2 \mathrm{ka})$, and the white pine period $(<3.2 \mathrm{ka})$. The boundary between the jack/red pine zone and the prairie zone is dated at $7.68 \pm 0.9 \mathrm{ka}$ from a piece of wood in core $\mathbf{J}$ from Williams Lake. The dates of the other zone boundaries were estimated from dates on bulk organic carbon and wood from nearby Bog D (McAndrews, 1966), Portage Lake (McAndrews et al., 1973), and Elk Lake (Anderson et al., 1993), and from Parkers Prairie (Almquist-Jacobson et al., 1992), $100 \mathrm{~km}$ to the southeast. For sediment description, magnetic susceptibility, loss-on-ignition, pollen stratigraphy and ostracode assemblages see Locke (1995) and Schwalb et al. (1995).

\section{Results and discussion}

\subsection{Oxygen and carbon isotope data}

Isotopic values for Shingobee Lake cover the entire Holocene, whereas those for Williams Lake only cover the early and mid-Holocene (Figs. 3-5). Ostracodes disappear in the Williams Lake core at about $480 \mathrm{~cm}$ (ca. $6 \mathrm{ka}$ ), whereas marl continued to accumulate for about 2000 more years to a depth of $320 \mathrm{~cm}$ (ca. $4 \mathrm{ka}$; Fig. 3). The range of the isotopic values for modern benthic ostracodes reflects the isotopic composition of the lake water within the annual temperature range of the bottom lake water from $4{ }^{\circ} \mathrm{C}$ to $12^{\circ} \mathrm{C}$ (Schwalb et al., 1995). Several ostracode species had to be used for isotopic analyses because none was present throughout the entire record. At levels where adult ostracodes were not abundant, juvenile ostracodes were analyzed. The maximum difference in isotopic values between adults of the same species, and adults from different species from the same sample level is about $3 \%$ for both $\delta^{18} \mathrm{O}$ and $\delta^{13} \mathrm{C}$. In our data set, consistent offsets between juveniles and adults are only shown for the values of $\delta^{18} \mathrm{O}$ in juveniles of Candona rawsoni from Williams Lake. They are about $1-2 \%$ lower than those for adults from the same level (Figs. 3 and 5). For other species, the difference between species, and juveniles and adults of the same species is not larger than the difference between replicates.

In Williams Lake, the most negative values of $\delta^{18} \mathrm{O}$ for lake water have been measured for samples taken in August 1989 at water depths below $7 \mathrm{~m}$ (Kendall et al., 1997). Surface waters in August 1989 were only enriched in $\delta^{18} \mathrm{O}$ by about $0.7 \%$ compared to water samples taken in April 1989 (Kendall et al., 1997). This suggests that differences in values of $\delta^{18} \mathrm{O}$ of ostracode valves mainly depend on water temperatures at time of valve formation. Valves that precipitate in summer will thus have lower values of $\delta^{18} \mathrm{O}$ due to a higher isotopic fractionation between water and valve calcite in warm waters than those that form in cooler waters during spring and fall. This suggests that juveniles of Candona rawsoni form their valves during summer, whereas the adults form their valves during the rest of the year. This is consistent with monthly field collections by Xia et al. (1997b) that showed that many juveniles apparently molt in mid-summer and persist as penultimate instars into the following spring.

Contrary to the isotopic composition of valves from benthic ostracodes that reflect the isotopic composition of the bottom waters, the isotopic composition of marl mainly reflects the isotopic composition and the temperature of the surface water. In Williams Lake admixtures of detrital carbonates are minor (Dean and Schwalb, in press). The isotopic record from marl in Williams Lake continues into the hardwood period (approximately $4 \mathrm{ka}$ ), whereas the ostracode record stops at about $6 \mathrm{ka}$, when ostracodes were no longer preserved in the sediments at the core site (Schwalb et al., 1995). Overall, isotope values from ostracodes show greater variability than those from marl.

The isotopic values for ostracodes in the Williams Lake core range between $-7 \%$ and $+3 \%$ for $\delta^{18} \mathrm{O}$, and between $-9 \%$ and $+3 \%$ for $\delta^{13} \mathrm{C}$ (Fig. 3), with distinct trends from lower to higher values for both oxygen and carbon. This indicates that these ostracode valves precipitated from lake water with increasing residence time (Talbot, 1990). The transition from the spruce to the jack/red pine zone is characterized by a positive shift in $\delta^{18} \mathrm{O}$ of about $4 \%$, and the lower prairie zone is characterized by an approximately $2 \%$ negative shift. These shifts are not seen in the oxygen isotopic composition of marl. The values of $\delta^{18} \mathrm{O}$ in marl are between $4 \%$ and $9 \%$ lower than in ostracodes, and values increase gradually by almost $10 \%$ throughout the entire lower to mid-Holocene section. Both the ostracode and the marl carbon-isotope curves are very similar, and increase by about $10 \%$ between 700 and $500 \mathrm{~cm}$ (ca. 10-7 ka). 


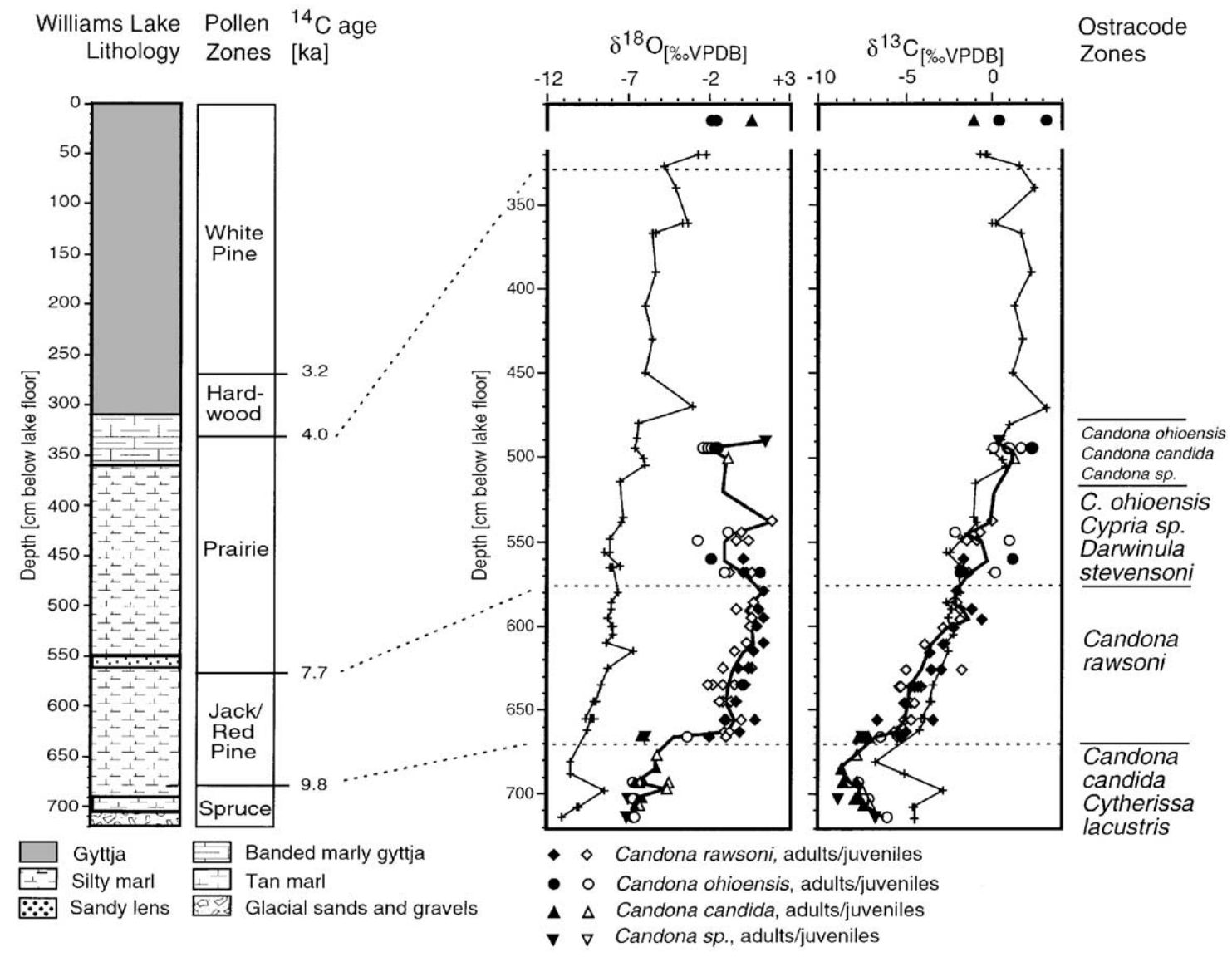

Fig. 3. Lithology, pollen zones, stable isotopic composition of ostracode valves and marl and ostracode zones from Williams Lake core J. The uppermost level represents modern ostracodes from a surface sediment sample taken at $3 \mathrm{~m}$ water depth. Filled symbols represent adult ostracodes, open symbols juveniles, $+=$ marl; thick line is based on average value per sample level. Chronostratigraphy is based on radiocarbon-dated pollen zones (uncalibrated ages; Locke, 1995; Schwalb et al., 1995).

The isotopic values for ostracodes in the Shingobee Lake core range between $-9 \%$ and $-4.5 \%$ for $\delta^{18} \mathrm{O}$, and between $-9.5 \%$ and $-3.5 \%$ for $\delta^{13} \mathrm{C}$ (Fig. 4), values that are typical of carbonate in an open lake basin with freshwater throughflow (Talbot, 1990). Overall, oxygen-isotope values and carbon-isotope values for both ostracodes and marl have maximum values during the prairie zone and lower values during the white pine zone of the late Holocene. The most significant feature of the ostracode oxygen-isotope curve is an approximately 4\%o negative shift in the upper prairie zone, following maxima in both the oxygenisotope and carbon-isotope curves. The oxygen-isotope record of marl is very uniform, and values of $\delta^{18} \mathrm{O}$ are between $3 \%$ and $6 \%$ lower than the values from ostracodes. Carbon-isotope values from marl are up to $3 \%$ higher than those from ostracodes. Differences in carbon-isotope values between marl and ostracodes are smallest in the middle of the prairie zone.

Before $9.8 \mathrm{ka}$, in the spruce zone, ostracodes have isotopic values that average about $-6 \%$ for $\delta^{18} \mathrm{O}$, and $-7.5 \%$ for $\delta^{13} \mathrm{C}$ in samples from both Williams and Shingobee Lakes. With the beginning of the jack/red pine zone, both lakes clearly show different evolutions of isotopic trends. Values of $\delta^{18} \mathrm{O}$ and $\delta^{13} \mathrm{C}$ in samples of ostracodes and marl from Williams Lake show an increase of about $4 \%$ for $\delta^{18} \mathrm{O}$ and $8 \%$ for $\delta^{13} \mathrm{C}$ with younger age through the middle of the prairie zone (Fig. 3). In Shingobee Lake, $\delta^{18} \mathrm{O}$ values remain low and uniform throughout the Holocene, but $\delta^{13} \mathrm{C}$ values increase by about $4 \%$ through the middle of the prairie zone. Values of $\delta^{18} \mathrm{O}$ and $\delta^{13} \mathrm{C}$ in modern ostracodes show a relatively wide range of about 2\%o (Fig. 4). Modern ostracodes from the Shingobee Lake core, have values of $\delta^{18} \mathrm{O}$ and $\delta^{13} \mathrm{C}$ that are similar to those of ostracodes from the white pine zone, whereas values of modern ostracodes from the Williams Lake core generally are similar to those of ostracodes from the prairie zone, just before truncation of the record. Today, ostracodes in Shingobee Lake are found at all depths. In Williams Lake, on the other hand, ostracodes are found at a maximum depth of $3 \mathrm{~m}$, because the calcitic valves are not preserved in deeper parts of the lake, and their $\delta^{18} \mathrm{O}$ values may thus be strongly controlled by changing water temperatures. 


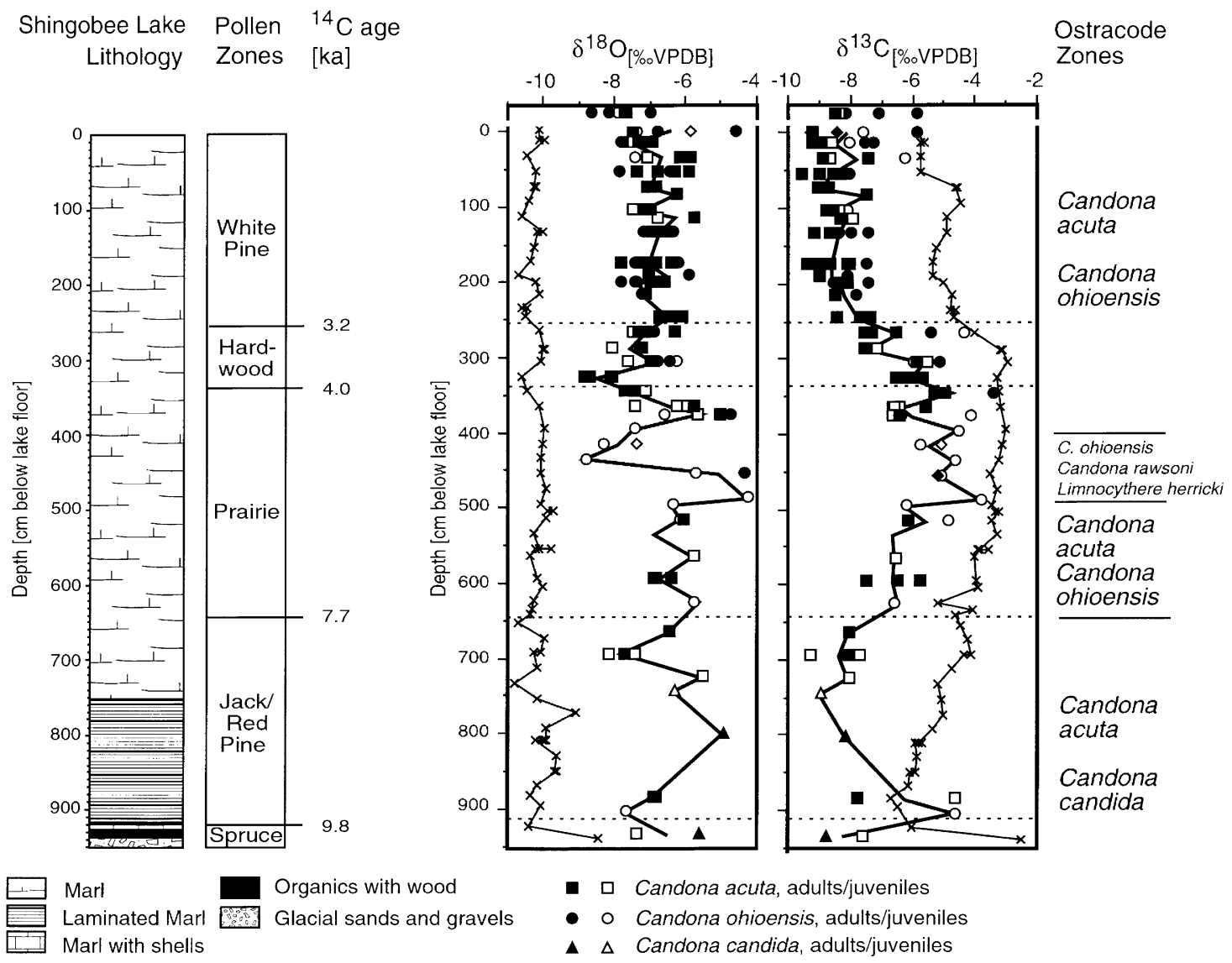

Fig. 4. Lithology, pollen zones, stable isotopic composition of ostracode valves and marl and ostracode zones from Shingobee Lake core H. The uppermost level represents modern ostracodes from a surface sediment sample taken at $7 \mathrm{~m}$ water depth. Filled symbols represent adult ostracodes, open symbols juveniles, $x=$ marl; thick line is based on average value per sample level. Chronostratigraphy is based on radiocarbon-dated pollen zones (uncalibrated ages; Locke, 1995; Schwalb et al., 1995).

\subsection{Hydrological stages of Williams and Shingobee Lakes}

Oxygen and carbon isotopic values often track the hydrological evolution of a lake (Talbot, 1990; Kelts and Schwalb, 1994). The isotopic compositions of these two lakes show very distinct evolution patterns through time (Fig. 5) that are closely linked to climate change as reflected in the vegetation history; therefore, pollen zones serve as time windows that represent steps in the lake's history. The higher variability of isotopic signatures from ostracodes in comparison to those from marls suggests that ostracodes may be more sensitive than marl to the influx of ground water, whereas the isotopic composition of marls reflects the long-term hydrologic trends.

\subsubsection{Spruce period ( $>9.8 \mathrm{ka}$ )}

The low and similar $\delta^{18} \mathrm{O}$ and $\delta^{13} \mathrm{C}$ values in both Williams and Shingobee Lakes during the spruce zone of the early Holocene suggest that calcite precipitation in ostracode valves occurred in a similar or the same water body. We suggest that Williams and Shingobee lakes were linked at this time and formed a much larger lake, which we will call Lake Willobee, for a time period of perhaps several hundred to a maximum of 1000 years. Such a lake could have formed briefly by an ice dam or mud flow across the Shingobee River downstream from Shingobee Lake (Fig. 2B). Once the ice dam was breached, the level of Lake Willobee went down and the remaining depressions filled to form the existing lakes and wetlands (Mooers and Norton, 1997). A former high lake level of unknown age, suggesting a large lake, is also indicated by the presence of lake marl about $7 \mathrm{~m}$ above the modern level of Williams Lake (Seaburg, 1985). The presence of Cytherissa lacustris in Williams Lake sediments (Schwalb et al., 1995) indicates a deep, well oxygenated, cold-water lake such as those found today in boreal forests of northern Canada and Alaska (Delorme, 1969, 1970; Danielopol et al., 1990). If there was a large lake, then Cytherissa lacustris also should have been found in Shingobee Lake sediments. At the present location of Shingobee Lake, Lake Willobee would have been $44 \mathrm{~m}$ deep: $24 \mathrm{~m}$ above the level of present Shingobee Lake plus $10 \mathrm{~m}$ of water in the present lake, plus $10 \mathrm{~m}$ of sediment that was not 

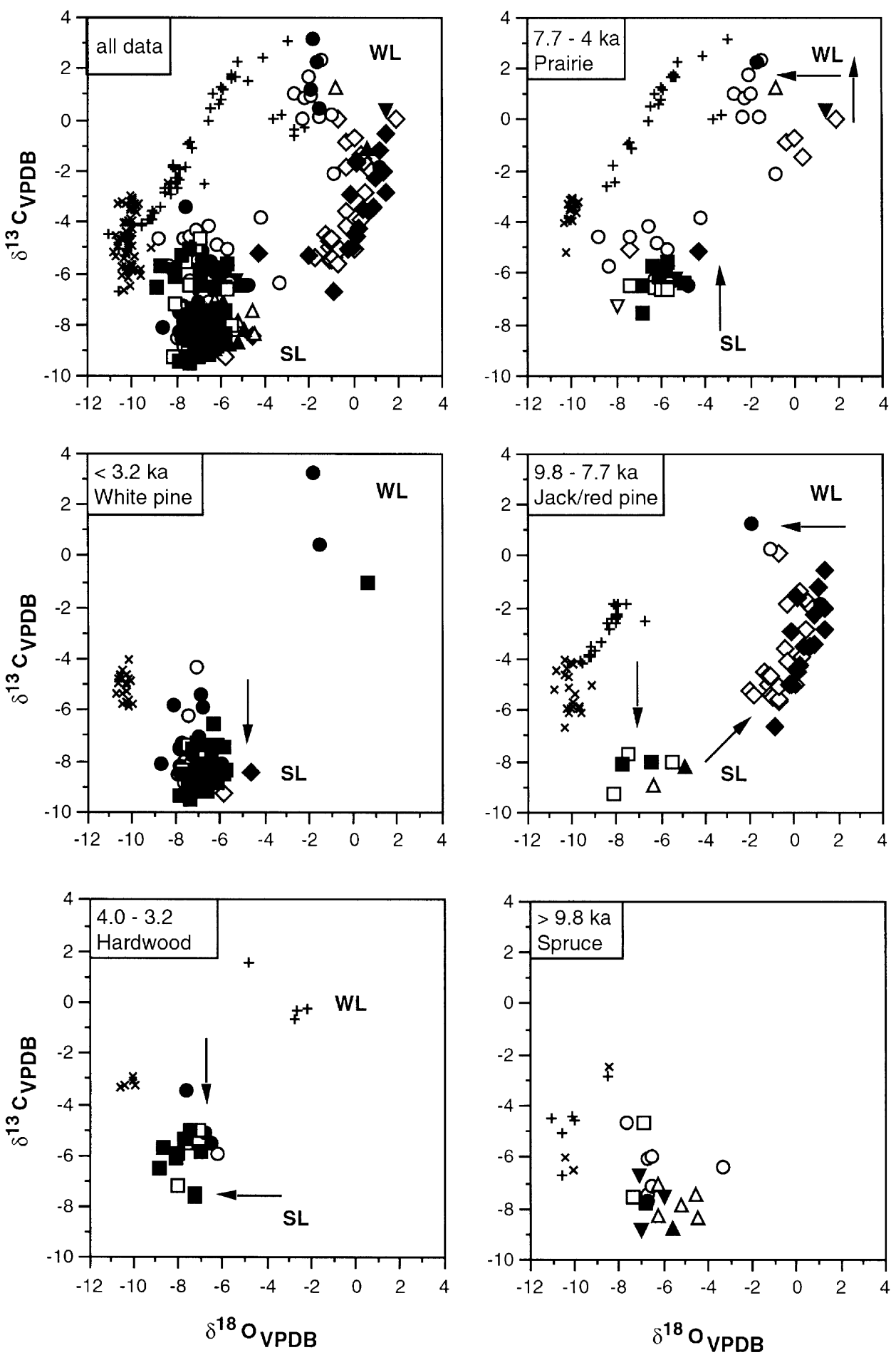

Fig. 5. Cross plots of $\delta^{18} \mathrm{O}$ versus $\delta^{13} \mathrm{C}$ for ostracode calcite for Williams (WL) and Shingobee Lakes (SL) divided into pollen zones representing hydrological stages of the lakes. Symbols are same as in Figs. 2 and 3. Arrows indicate main trends in the isotope patterns. The time window of the White pine period includes modern data for both lakes. Ages are given in uncalibrated radiocarbon years.

deposited yet. At a depth of $44 \mathrm{~m}$, it is possible that the lake was deep enough to cause an oxygen-depleted hypolimnion during summer stratification. This created an environment with (1) insufficient oxygen to support ostracodes, especially the oxygen-sensitive Cytherissa lacustris and (2) dissolution of ostracode valves, as suggested by the very low total numbers of valves and the presence of laminated sediments (Schwalb et al., 1995; Fig. 4). Decomposition of organic matter in the hypolimnion probably decreased the $\mathrm{pH}$ of the hypolimnion causing greater dissolution of $\mathrm{CaCO}_{3}$, especially in ostracode valves, and a decrease in the rain rate of 
$\mathrm{CaCO}_{3}$ to the sediment-water interface (Dean, 1999; Dean and Schwalb, in press).

\subsubsection{Jack/red pine period $(9.8-7.7 \mathrm{ka})$}

The trend to higher values of $\delta^{18} \mathrm{O}$ and $\delta^{13} \mathrm{C}$ in ostracodes and marl from Williams Lake in this interval suggests higher evaporation rates and an increase in water residence time for Williams Lake. Increasing magnetic susceptibility in both Williams and Shingobee Lake sediments indicates increased clastic input due to enhanced catchment runoff (Schwalb et al., 1995) and/or frequent lake level changes. The sudden shift to higher values of $\delta^{18} \mathrm{O}$ in ostracodes in Williams Lake shortly after $9.8 \mathrm{ka}$ implies a rather sudden change in hydrology that affected bottom waters but not surface waters. Once the level of Lake Willobee dropped, and the large lake was reduced to separate small basins, Williams Lake became hydrologically isolated. The similar carbonisotope values, and different oxygen-isotope values of ostracodes and marl from Williams Lake suggest that both precipitated from waters with the same dissolved inorganic carbon (DIC) but different oxygen isotopic composition. The difference between ostracode and marl $\delta^{18} \mathrm{O}$ values of about $2 \%$ in Shingobee Lake sediments (Figs. 4 and 5) probably results from differences between surface (marl) and bottom water (ostracode) temperatures. The difference of up to $9 \%$ in Williams Lake sediments (Figs. 3 and 5) is too large to be solely due to water temperature differences. Also, the ostracode species assemblage is dominated by Candona rawsoni that favors highly variable conditions in the littoral zone (R.M. Forester, personal communication). Therefore, we suggest that after the level of Lake Willobee dropped, a highly evaporative and isolated littoral zone was suddenly created, and the thickness and oxygen content of the hypolimnion decreased. Benthic ostracodes could thus not survive in the deeper bottom waters of Williams Lake. The high $\delta^{18} \mathrm{O}$ values of Candona rawsoni reflect the evaporative concentration of the lake water in the littoral zone and were swept out into the open lake during frequent lake-level changes. The similar $\delta^{13} \mathrm{C}$ values for both marl and ostracodes from Williams Lake suggest that photosynthetic productivity was low and/or mixing of the water column was high. In Shingobee Lake, values of $\delta^{13} \mathrm{C}$ in ostracodes and marl are the same at $9.8 \mathrm{ka}$ but diverge rapidly thereafter. This reflects the increase of photosynthetic activity and decrease of ${ }^{12} \mathrm{C}$ in the surface water DIC and consequently higher $\delta^{13} \mathrm{C}$ in marls; and transfer and decay of ${ }^{12} \mathrm{C}$-enriched organic matter in the bottom waters leading to lower $\delta^{13} \mathrm{C}$ values in ostracodes.

\subsubsection{Prairie period (7.7-4 ka)}

The trend to higher $\delta^{13} \mathrm{C}$ values in both lakes (Figs. 35) that started during the jack/red pine period reached highest values during the prairie period, may reflect a change in dominant vegetation from $\mathrm{C}_{3}$ forest vegetation to $\mathrm{C}_{4}$ prairie grasses (Kelts and Schwalb, 1994; Dean and Schwalb, in press). Change to prairie vegetation also lead to more positive $\delta^{13} \mathrm{C}$ values in stalagmites from Cold Water Cave in northeastern Iowa (Baker et al., 1998). The spatial change from $C_{3}$ to $C_{4}$ vegetation within the USA correlates with increasing mean July temperature (Teeri and Stowe, 1976). A parallel increase of $\delta^{13} \mathrm{C}$ of organic carbon in both lakes during the mid-Holocene (Dean and Schwalb, in press) further suggests that vegetation change was the main cause for the 3\% increase in $\delta^{13} \mathrm{C}$ of marl in Shingobee Lake, and $3 \%$ of the $10 \%$ increase in $\delta^{13} \mathrm{C}$ of marl in Williams Lake. The remaining 7\%o increase resulted from differences in residence time (Dean and Schwalb, in press), because today, average values of $\delta^{13} \mathrm{C}$ of DIC in Williams Lake are about $7 \%$ o more ${ }^{13} \mathrm{C}$-enriched relative to average Shingobee Lake DIC (R. G. Striegl, personal communication). A shift to higher values of both $\delta^{13} \mathrm{C}$ and $\delta^{18} \mathrm{O}$ during the mid-Holocene was also found in marl from Elk Lake, northwestern Minnesota (Dean and Stuiver, 1993; Dean et al., in press), and in marl from Pickerel Lake in northeastern South Dakota (Stuiver, 1970; Schwalb and Dean, 1998; Dean and Schwalb, 2000). This shift is synchronous with the eastward expansion of oak savanna and prairie that is well documented for the north-central United States (Webb et al., 1983; Jacobson et al., 1987; Whitlock et al., 1993; Baker et al., 1998). These studies suggest that the maximum expansion of prairie in the north-central USA occurred between 7 and $6 \mathrm{ka}$. In Williams and Shingobee Lakes, the decrease in abundance of valves from benthic ostracodes and an increase of valves from nektic ostracodes, indicates an increased input of clastic- and ostracode-rich sediment from the littoral zone resulting from a lowered lake level (Schwalb et al., 1995). The comparison of more recent studies from lake sediments in the north-central USA, however, shows that maximum aridity that should reflect the maximum expansion of prairie, occurred between 8.5 and 4 ka (Fig. 6), and was not related to the location of a specific lake on the effective moisture gradient (Fig. 1B).

An increase in aridity should have resulted in higher $\delta^{18} \mathrm{O}$ values. For Shingobee Lake, however, the $\delta^{18} \mathrm{O}$ values remain unchanged throughout the lower prairie period. A shift to lower $\delta^{18} \mathrm{O}$ values in ostracodes occured in Williams Lake during the prairie period at about $7 \mathrm{ka}$ (Fig. $3,550 \mathrm{~cm}$ ), and in Shingobee Lake at about $5 \mathrm{ka}$ (Fig. 4, 400-450 cm) but does not occur in bulk marl in either core. This does not fit with an interpretation of an arid prairie period. Instead, it seems to be related to a change in lake hydrology, probably to the discharge of isotopically less evolved ground water that affected bottom waters (recorded by ostracodes) but not surface waters (recorded by marl). Today, $\delta^{18} \mathrm{O}$ values for ground water entering Williams Lake are 


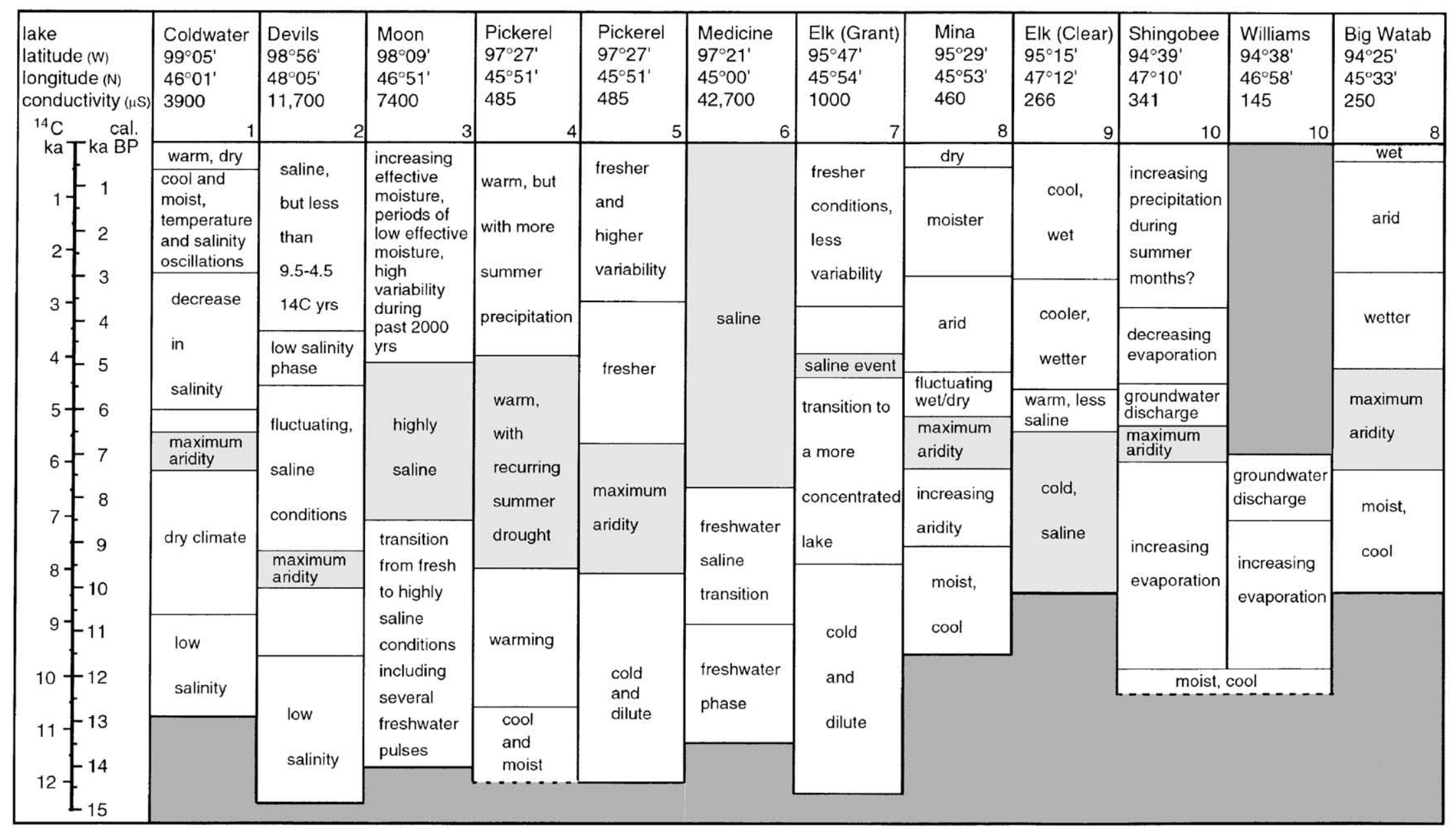

Fig. 6. Comparison of Holocene paleoclimate reconstructions based on stable oxygen and carbon isotopes in carbonates, trace elements and biological remains from selected lake sites covering the entire Holocene record in the North-central USA. ${ }^{1}$ Xia et al. $(1997 \mathrm{c})^{\mathrm{u}}$, ${ }^{2}$ Haskell et al. $(1996)^{\mathrm{u}},{ }^{3}$ Laird et al. $(1996,1998)^{\mathrm{c}}$, Valero-Garcés et al. $(1997)^{\mathrm{u}}{ }^{4}{ }^{4}$ Watts and Bright $(1968)^{\mathrm{u}},{ }^{5}$ Schwalb and Dean $(1998)^{\mathrm{u}}$, Dean and Schwalb $(2000)^{\mathrm{u}, \mathrm{c}},{ }^{6}$ Valero-Garcés and Kelts $(1995)^{\mathrm{u}},{ }^{7}$ Smith et al. $\left.(1997)\right)^{\mathrm{u}},{ }^{8}$ Stevens, $1997^{\mathrm{u}},{ }^{9}$ Dean and Stuiver $(1993)^{\mathrm{v}}$, and ${ }^{10}$ Schwalb et al.

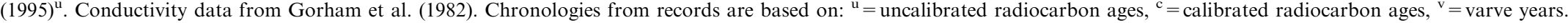


about 5\% lower than those for the lake water (Kendall et al., 1997). Williams Lake is the second highest in a chain of lakes drained by the Shingobee River and is controlled today by discharge of ground water coming from the highest lake of this chain, Crystal Lake, situated south and east of Williams Lake (Fig. 2; Siegel and Winter, 1980). Seepage from Crystal Lake moves through the ground water system to Williams Lake (Winter and Rosenberry, 1997). This ground water discharge results in a sensitive response of the lake to changing precipitation and temperature, with annual fluctuations in lake level of about $0.5 \mathrm{~m}$ (T.C. Winter, unpublished data).

We propose the following scenario. As the lake level in Williams Lake dropped during the arid jack/red pine and prairie periods, the water table gradient steepened and ground water discharge from Crystal Lake increased. With the drop in lake level of about $4 \mathrm{~m}$ (Locke, 1995), the thickness of the hypolimnion and thus the oxygen content decreased to a level insufficient to support an ostracode fauna. The connection between falling lake levels, anoxic hypolimnion, and increase in hypolimnetic Mn-concentration was observed between 1988 and 1991 when the level of Williams Lake dropped about $1 \mathrm{~m}$ (Dean and Schwalb, in press).

The difference in timing of groundwater input between the two lakes is a result of the hydrology as well. Williams Lake, being controlled by ground water inflow and outflow, reacts more sensitively and faster to changes in effective moisture, whereas Shingobee Lake is buffered by the river. However, the absence of Candona acuta, an indicator for flowing water (R.M. Forester, personal communication), and the presence of Candona rawsoni during a short period within the upper prairie zone of the Shingobee Lake record (Fig. 4) indicates that the throughflow rate must have decreased and evaporative concentration of lake water must have increased significantly at this time. Similar values of $\delta^{13} \mathrm{C}$ for both ostracodes and marl suggest that Shingobee Lake was shallower and well mixed just before the negative excursion in ostracode $\delta^{18} \mathrm{O}$ values at about $5 \mathrm{ka}$ and the return of Candona acuta indicate an increase in the in- and throughflow rate.

\subsubsection{Hardwood period (4-3.2 ka)}

The shift to lower values of $\delta^{18} \mathrm{O}$ in ostracodes from Shingobee Lake from the upper part of the prairie period to the lower part of the hardwood period, and the dominance of Candona ohioensis and Candona acuta suggest fresher conditions and higher throughflow rates caused by increased ground water input. The trend to lower values of $\delta^{13} \mathrm{C}$ in both ostracodes and marl (Fig. 4) probably reflects a change in vegetation from mainly $\mathrm{C}_{4}$ prairie grasses to $\mathrm{C}_{3}$ forest vegetation. All proxies suggest an increase in effective moisture result- ing from a decrease in evaporation and increase in precipitation that resulted in reforestation.

\subsubsection{White pine period $(<3.2 \mathrm{ka})$}

The trend to lower values of $\delta^{13} \mathrm{C}$ in ostracode calcite from Shingobee Lake, begun in the hardwood period, continued during the white pine period, reflecting the abundant ${ }^{12} \mathrm{C}$ provided to soils by $\mathrm{C}_{0}$ plants in the forest. This trend is paralleled by a trend to lower values of $\delta^{13} \mathrm{C}$ in organic carbon (Dean and Schwalb, in press). Values of $\delta^{13} \mathrm{C}$ are as much as $4 \%$ higher in marl than in ostracodes suggesting a significant photosynthetic productivity in the epilimnion. Considering the change in vegetation and the increased moisture, hinting at high river throughflow rates, as indicated by the dominance of Candona acuta, we suggest an increase of precipitation during summer months providing more Gulf moisture to the north-central USA. In Williams Lake, the establishment of a denser forest led to a decrease in detrital clastic input and provided protection from strong, wind-induced turbulence, leading to a decrease in mixing and further oxygen deficiency in the hypolimnion (Locke, 1995). If ostracodes existed, their calcitic valves would have been dissolved along with any other carbonate in the hypolimnion and anoxic sediments.

\subsection{Timing of the onset of early Holocene aridity in the Great Plains}

The comparison of Holocene paleoclimate reconstructions based on stable oxygen and carbon isotopes and trace elements in carbonates, and biological remains from selected lake sites illustrates timing inconsistency regarding the onset of early Holocene aridity in the Great Plains (Fig. 6). Moon Lake and Devils Lake at the western and high cation end of the salinity gradient (Fig. 1B), show a clear early transition to more saline conditions before $9.5 \mathrm{ka}$ (Haskell et al., 1996; Laird et al., 1996, 1998; Valero-Garcés et al., 1997) whereas Pickerel Lake (Watts and Bright, 1968; Schwalb and Dean, 1998; Dean and Schwalb, 2000) and Elk Lake, Grant County, Minnesota (Smith et al., 1997), change up to 2000 years later (Fig. 6). Also, the early Holocene aridity maximum is reached at Devils Lake (Haskell et al., 1996) at $8 \mathrm{ka}$, about 2500 years earlier than at Coldwater Lake (Xia et al., 1997c). Lowest lake levels and high magnetic susceptibilities, indicating a time of maximum aridity beginning about $7 \mathrm{ka}$, were observed in Elk Lake, Clearwater County, Minnesota, $45 \mathrm{~km}$ to the northwest (Forester et al., 1987; Sprowl and Banerjee, 1993), at Parkers Prairie, approximately $100 \mathrm{~km}$ to the south (Almendinger et al., 1994), in Lake Ann, approximately $150 \mathrm{~km}$ to the southeast (Keen and Shane, 1990) of Williams and Shingobee Lakes, and also in Lake Michigan (Colman et al., 1990). The end of the prairie 
period is characterized by a saline event for Elk Lake, Grant County (Smith et al., 1997), as indicated by ostracodes at about $4 \mathrm{ka}$, whereas the records from Coldwater Lake (Xia et al., 1997c), Devils Lake (Haskell et al., 1996) and Shingobee Lake (Schwalb et al., 1995) indicate decreasing salinities. Pollen and isotopic evidence from Elk Lake, Clearwater County, indicate cooler and wetter conditions beginning at about $3.5 \mathrm{ka}$ (Dean and Stuiver, 1993; Whitlock et al., 1993). The present study shows that the expression of the climate history recorded in the lake sediments is mediated by changes in the watershed hydrology. The hydrology certainly responds to climate change, but the climate signals we interpret from different proxies may point in opposite directions. Streamflow-dominated Shingobee Lake responded about 2000 years later to the early Holocene increase in aridity than the hydrologically isolated Williams Lake, and helps to explain the observed differences about the timing of the onset of early Holocene aridity in the Great Plains.

\subsection{Different proxies in the same record may tell contrary stories}

In addition to problems with the timing of the early Holocene aridity maximum, there are contrasts between different proxies from the same lake record. The shifts to lighter $\delta^{18} \mathrm{O}$ values during the prairie period in ostracode valves from Williams and Shingobee Lakes seems to be an apparent contradiction for an arid period, and reflect discharge of isotopically lighter ground water (Schwalb et al., 1995). Smith et al. (1997) showed that during the middle Holocene drought, the ground water catchment of Elk Lake, Grant County, Minnesota, expanded and the lake received additional flow of less-isotopically evolved water enriched with solutes from till. This led to a dominance of halophylic ostracode assemblages and a decrease in $\delta^{18} \mathrm{O}$ values. Prairie vegetation surrounded Pickerel Lake, South Dakota, at about $10.5 \mathrm{ka}$ (Watts and Bright, 1968) when brackish-water diatoms indicate an increase in the mineral content of the water (Haworth, 1972), whereas isotopes responded later and more gradually. Values of $\delta^{18} \mathrm{O}$ and $\delta^{13} \mathrm{C}$ in marl and $\delta^{13} \mathrm{C}$ in organic matter increased between 10 and $6 \mathrm{ka}$ as residence time increased and as prairie grasses moved in (Dean and Schwalb, 2000). Valero-Garcés and Kelts (1995) interpreted rapid fluctuations in the water cycle in Medicine Lake during both the middle and late Holocene based on sedimentologic and isotopic evidence that had not been revealed in diatom and pollen studies (Allen, 1994). A large degree of variability characterizes the geochemistry of endogenic carbonate and fossil ostracodes from Devils Lake, North Dakota, where trace elements and stable isotopes exhibit different behavior (Haskell et al., 1996). In Moon Lake, North Dakota, biological, sedimentological, isotopic, and chemical proxies occasionally were out of phase, suggesting that evaporation was not the only control of lake-water chemical and isotopic composition (Laird et al., 1996, 1998; Valero-Garcés et al., 1997). The ostracode record from Harris Lake, southwestern Saskatchewan, generally corroborates the interpretations of proxy data from pollen and diatoms. Most of the discrepancy involves the timing and severity of maximum Holocene warmth and aridity (Porter et al., 1999).

Differences among proxy data of the same lake record and between neighboring lakes are also seen, for example, in modern lake water data sets (R.M. Forester, unpublished data, 1991). They show that conductivity and total dissolved solids (TDS) can vary significantly within an annual cycle. Some of the lakes in the Northern Great Plains show increasing conductivity and TDS from spring to summer, and some show decreasing conductivity for the same period. Lakes that are located close to each other may display extreme differences in conductivity and TDS. The extreme difference in salinity of neighboring lakes can be seen in the conductivity data for Pickerel and Medicine Lake with 485 and $42700 \mu \mathrm{m} \mathrm{S}$, respectively (Fig. 6). Also, the isotopic composition of the lake water can vary significantly within a season. In the Dakotas, Xia (unpublished data) measured a variability of up to $2 \%$ in lake water $\delta^{18} \mathrm{O}$. Some of the sampled lakes show $\delta^{18} \mathrm{O}$ maxima during summer, indicating evaporative enrichment, some show minima, indicating ground water recharge.

In the north-central USA, glacial deposits with high permeability allow the interaction of local, intermediate, and regional ground water flow systems with lakes and wetlands. Lakes having highly mineralized water receive discharge from regional or deep intermediate flow systems that interact with underlying Cretaceous shales containing interbedded carbonate and evaporite rocks, and are recharged at major topographic highs. Nearby lakes having less mineralized water receive discharge from shallow intermediate flow systems, and ground water from these local flow systems discharges into nearly all lakes and wetlands, whether topographically high or low (Winter et al., 1998). Consequently, differences in water chemistry often are related to hydrology, bedrock geology, and/or surficial geology and not necessarily to climate. Also, changes in the volume and/or concentrations of chemical constituents in the seepage to a lake could have a large effect on the chemical balance of the lake water (LaBaugh et al., 1997).

Conflicting results are obtained from lakes in topographic lows, often in glacial outwash areas, where deep, regional ground water discharges as in Elk Lake, Grant County, Minnesota (Smith et al., 1997) and Medicine Lake, South Dakota (Valero-Garcés et al., 1997). An input of ground water from deeper flow systems with higher contents of dissolved solids could, for example, 
change the water chemistry and hence ostracode and diatom species assemblages. The fauna may indicate saline conditions, whereas the isotopic signatures reflect less isotopically evolved waters and would rather suggest fresh conditions. In the glaciated Northern Great Plains, isolated lakes on topographic highs in till, for example Rice Lake, North Dakota (Yu and Ito, 1999), and Pickerel Lake, South Dakota (Dean and Schwalb, 2000), are mainly controlled by local ground water flow, and thus are more likely to reflect climate change. Gradients in major ion concentrations in the lakes within the Shingobee River headwaters area mainly are related to their hydrologic setting. Lakes with lower concentrations such as Williams Lake are those located high in the ground water flow system, and in which the water balance is determined by atmospheric exchange and loss to ground water (Winter et al., 1998).

\section{Conclusions}

The results of this study suggest that a large lake, Lake Willobee, existed until about $9.8 \mathrm{ka}$, possibly caused by an ice dam or mud flow across the Shingobee River. Once the dam breached, remnants of Lake Willobee filled depressions in the lake floor forming the present lakes and wetlands in the Shingobee headwaters; Shingobee and Williams are two of these lakes. Prior to $9.8 \mathrm{ka}$, the ostracodes and marls in both lakes (then Lake Willobee) had similar values of $\delta^{18} \mathrm{O}$ and $\delta^{13} \mathrm{C}$. Once they became separate lakes, however, the trend to higher $\delta^{18} \mathrm{O}$ and $\delta^{13} \mathrm{C}$ values for ostracodes and marl from Williams Lake indicates that the lake became isolated after $9.8 \mathrm{ka}$ and transformed to a closed-lake system by about $7 \mathrm{ka}$ controlled by ground water discharge, as it is today. The lower $\delta^{18} \mathrm{O}$ and $\delta^{13} \mathrm{C}$ values for ostracodes and marl from Shingobee Lake in comparison to the increasing values in ostracodes and marl in Williams Lake indicate that Shingobee Lake probably remained open throughout the Holocene. The level of Williams Lake probably reached a low-stand at about $7.7 \mathrm{ka}$, followed by ground water discharge into Williams Lake at about $7 \mathrm{ka}$. The low lake level during the prairie period led to a decrease in thickness of the hypolimnion and thus to a decrease in oxygen and ultimately to the extinction of benthic ostracodes. Because Shingobee Lake is buffered by the Shingobee River, and because it receives local as well as regional ground water flow, maximum aridity followed by a period of augmented ground water discharge occurred later at about $5 \mathrm{ka}$. After $4 \mathrm{ka}$, moister conditions are indicated by the return of forest vegetation to the region, and of Candona acuta to the lake, indicating increasing throughflow rates. Slightly higher $\delta^{18} \mathrm{O}$ values of ostracodes from Shingobee Lake in sediments deposited after $4 \mathrm{ka}$ suggest that there was increasing summer precipitation and hence increasing importance of meridional flow patterns. Vegetation and carbon burial is well reflected in the carbon-isotope record with higher $\delta^{13} \mathrm{C}$ values during the prairie period (7.7-4 ka) and lower values during preceding and succeeding forest periods.

This study shows that changing ground water hydrology in a watershed can override the climate signal in the lake water chemistry response to changes in effective moisture. An inflow of less isotopically evolved ground water during an arid period, triggered by drought and falling lake levels, can even simulate an increase in effective moisture.

The comparison between ostracode and marl isotopic signals shows that changes in ground water hydrology are only recorded by benthic ostracodes, whereas the isotopic signatures of marls reflect the general evolution of lake water residence time and vegetation changes in the catchment. Also, different proxies may archive different signals. This suggests that (1) the response to the early Holocene increase in aridity and (2) divergence observed between proxies from the same archive depend on a lake's location in the hydrologic flow system.

The local surficial and bedrock geology, and the location of a lake within a hydrologic flow path is evidently critical and needs to be explored prior to work on lake sediment cores. Reconstruction of effective moisture from lake sediments seems to work well in lakes on topographical highs that are underlain by till and that receive predominantly local ground water flow. These lakes show little seasonal variability in lake water chemistry. Also, independent biotic and geochemical proxies from the same lake record need to be combined.

\section{Acknowledgements}

We wish to thank Jim Burdett for providing the stable-isotope analyses; Rick Forester, Tom Winter, Jim LaBaugh, Don Rosenberry and Juanjuan Xia for invaluable discussions and sharing of unpublished data. We also like to thank Jonathan Holmes and Pat Bartlein for their constructive reviews. This research was supported through fellowships to A.S. by the Swiss National Science Foundation and the Deutsche Forschungsgemeinschaft, as well as through the USGS Global Change and Climate History Program (W.E.D).

\section{References}

Allen, K.K., 1994. Early Holocene geochemical evolution of saline Medicine Lake, South Dakota. Journal of Paleolimnology 10, 6984.

Almendinger, J.E., Almendinger, J.C., Wovcha, D.S., Cushing, E.J., 1994. Holocene paleohydrology and vegetation dynamics on sand plains at the prairie/forest border, west-central Minnesota. Amer- 
ican Quaternary Association Field Guides of the 13th Biennial Meeting, 19-22 June, pp. G-1-G-23.

Almquist-Jacobson, H., Almendinger, J.E., Hobbie, S., 1992. Influence of terrestrial vegetation on sediment-forming processes in kettle lake of west-central Minnesota. Quaternary Research 38, 103-116.

Anderson, R.Y., Dean, W.E., Bradbury, J.P., 1993. Elk Lake in perspective. In: Bradbury, J.P., Dean, W.E. (Eds.), Elk Lake, Minnesota: Evidence for Rapid Climate Change in the NorthCentral United States. Boulder, Colorado, Geological Society of America Special Paper, 276, pp. 1-5.

Baker, R.G., Gonzalez, L.A., Raymo, M., Bettis III, E.A., Reagan, M.K., Dorale, J.A., 1998. Comparison of multiple proxy records of Holocene environments in the midwestern United States. Geology 26 (12), 1135-1138.

Bryson, R.A., Hare, F.K., 1974. Climates of North America. In: Landsberg, H.E. (Ed.), World Survey of Climatology. Elsevier, New York, pp. 11.

Colman, S.M., Jones, G.A., Forester, R.M., Foster, D.S., 1990. Holocene paleoclimatic evidence and sedimentation rates from a core in southwestern Lake Michigan. Journal of Paleolimnology 4, 269-11284.

Danielopol, D.L., Olteanu, R., Löffler, H., Carbonel, P., 1990. Present and past geographical-ecological distribution of Cytherissa (Ostracoda, Cytherideidae). Bulletin de l'Institut de Géologie du Bassin d'Aquitaine Bordeaux 47, 97-118.

Dean, W.E., 1999. The carbon cycle and biogeochemical dynamics in lake sediments. Journal of Paleolimnology 21, 375-393.

Dean, W.E., Bradbury, J.P., 1997. Transects of organic carbon, calcium carbonate, and diatoms in surface sediments of Williams and Shingobee Lakes. In: Winter, T.C. (Ed.), Interdisciplinary Research Initiative: Hydrological and Biogeochemical Research in the Shingobee River Headwaters Area, North-Central Minnesota. U.S. Geological Survey, Water Resources Investigations Research 96-4215, pp. 117-130.

Dean, W.E., Schwalb, A., 2000. Holocene environmental and climatic change in the northern Great Plains as recorded in the geochemistry of sediments in Pickerel Lake, South Dakota. Quaternary International 67, 5-20.

Dean, W.E., Schwalb, A., in press. The lacustrine carbon cycle as illuminated by the waters and sediments of two hydrologically distinct hardwater lakes in northwestern Minnesota.

Dean, W.E., Stuiver, M., 1993. Stable carbon and oxygen isotope studies of the sediments of Elk Lake, Minnesota. In: Bradbury, J.P., Dean, W.E. (Eds.), Elk Lake, Minnesota: Evidence for Rapid Climate Change in the North-Central United States. Boulder, Colorado, Geological Society of America Special Paper, 276, pp. 162-189.

Dean, W.E., Forester, R.M., Bradbury, J.P., in review. Early Holocene change in atmospheric circulation in the Northern Great Plains: an upstream view of the $8.2 \mathrm{ka}$ cold event.

Delorme, L.D., 1969. Ostracodes as Quaternary paleoecological indicators. Canadian Journal of Earth Sciences 6, 1471-1476.

Delorme, L.D., 1970. Freshwater ostracodes of Canada. Part IV. Families Ilyocyprididae, Notodromadidae, Darwinulidae, Cytherideidae and Entocytheridae. Canadian Journal of Zoology 48 (6), 1257.

Delorme, L.D., 1991. Ostracoda. In: Thorp, J.H., Covich, A.P. (Eds.), Ecology and Classification of North American Freshwater Invertebrates. Academic Press, New York, pp. 691.

Erickson, D.R., 1981. A study of littoral groundwater seepage at Williams Lake, Minnesota, using seepage meters and wells. MS Thesis, University of Minnesota, Minneapolis.

Forester, R.M., Delorme, L.D., Bradbury, J.P., 1987. Mid-Holocene climate in northern Minnesota. Quaternary Research 28, 263-273.

Fritz, S.C., 1996. Paleolimnological records of climatic change in North America. Limnology and Oceanography 41 (5), 882-889.
Fritz, S.C., Ito, E., Yu, Z., Laird, K., Engstrom, D.R., 2000a. Hydrologic variation in the northern Great Plains during the last two millennia. Quaternary Research 53, 175-184.

Fritz, S.C., Metcalfe, S.E., Dean, W.E., 2000b. Holocene climate of the Americas inferred from paleolimnological records. In: Markgraf, V. (Ed.), Interhemispheric Climate Linkages. Academic Press, New York.

Gorham, E., Dean, W.E., Sanger, J.E., 1982. The chemical composition of lake waters in Wisconsin, Minnesota, North Dakota and South Dakota. US Geological Survey Open-file Report, pp. 82-149.

Gorham, E., Dean, W.E., Sanger, J.E., 1983. The chemical composition of lakes in the North-Central United States. Limnology and Oceanography 28, 287-301.

Haskell, B.J., Engstrom, D.R., Fritz, S.C., 1996. Late Quaternary paleohydrology in the North American Great Plains inferred from the geochemistry of endogenic carbonate and fossil ostracodes from Devils Lake, North Dakota, USA. Palaeogeography, Palaeoclimatology, Palaeoecology 124, 179-193.

Haworth, E.Y., 1972. Diatom succession in a core from Pickerel Lake, Northeastern South Dakota. Geological Society of America Bulletin 83, 157-172.

Jacobson Jr., G.L., Webb III, T., Grimm, E.C., 1987. Patterns and rates of vegetation change during the deglaciation of eastern North America. In: Ruddiman, W.F., Wright Jr., H.E. (Eds.), North America and Adjacent Oceans During the Last Deglaciation, Geological Society of America, The Geology of North America, K3. Boulder, CO, pp. 277-288

Keatings, K.W., 2000. The basis for ostracod shell chemistry in paleoclimate reconstruction. Ph.D. Thesis, Kingston University, United Kingdom.

Kelts, K., Schwalb, A., 1994. Stable isotope stratigraphy of regional environmental dynamics from lacustrine archives. Terra Nostra 1/ 94, 115-119.

Kendall, K., Evans, W.C., Reddy, M.M., Schuster, P.F., 1997. Applications of stable isotopes in the Shingobee River Headquarters area. In: Winter, T.C., Averett, R.C. (Eds.), Hydrology of Shingobee and Williams Lakes, North-Central Minnesota. US Geological Survey Water-Resources Investigations Report, 964215, pp. 63-69.

LaBaugh, J.W., Winter, T.C., Swanson, G.A., Rosenberry, D.O, Nelson, R.D., Euliss Jr., N.H., 1996. Changes in atmospheric circulation patterns affect mid-continent wetlands sensitive to climate. Limnology and Oceanography 41, 864-870.

LaBaugh, J.W., Winter, T.C., Rosenberry, D.O., Schuster, P.F., Reddy, M.M., Aiken, G.R., 1997. Hydrological and chemical estimates of the water balance of a closed-basin lake in north central Minnesota. Water Resources Research 33 (12), 2799-2812.

Laird, K.R., Fritz, S.C., Grimm, E.C., Mueller, P.G., 1996. Centuryscale paleoclimatic reconstruction from Moon Lake, a closed-basin lake in the northern Great Plains. Limnology and Oceanography 41 (5), 890-902.

Laird, K.R., Fritz, S.C., Cumming, B.F., Grimm, E., 1998. Early Holocene limnological and climatic variability in the northern Great Plains. The Holocene 8, 275-286.

Lister, G.S., 1988. Stable isotopes from lacustrine Ostracoda as tracers for continental palaeoenvironments. In: DeDeckker, P., Peypouquet, J.P. (Eds.), Ostracoda in the Earth Sciences. Elsevier, Amsterdam, pp. 201-208.

Locke, S.M., 1995. A paleohydrologic model applied to the Holocene sediment stratigraphy of two lakes in north-central Minnesota. Ph.D. Dissertation, University of Minnesota, 258pp.

Locke, S.M., Schwalb, A., 1997. Sediment stratigraphy and paleolimnological characteristics of Williams and Shingobee Lakes. In: Winter, T.C., Averett, R.C. (Eds.), Hydrology of Shingobee and Williams Lakes, North-Central Minnesota. US Geological 
Survey Water-Resources Investigations Report, 96-4215, pp. 187-192.

McAndrews, J.H., 1966. Postglacial history of prairie, savanna, and forest in northwestern Minnesota. Torrey Botanical Club Memoir 22, pp. 1-72.

McAndrews, J.H., Berti, A.H., Norris, G., 1973. Key to the Quaternary Pollen and Spores of the Great Lakes Region. Royal Ontario Museum of Life Sciences Miscellaneous Publications, Vol. 61, 61pp.

Meltzer, D.J., 1999. Human response to middle holocene (altithermal) climates on the North American Great Plains. Quaternary Research 52, 404-416.

Mooers, H.D., Norton, A.R., 1997. Glacial landscape evolution of the Itasca/St. Croix moraine interlobate area including the Shingobee River headwaters area. In: Winter, T.C. (Ed.), Hydrological and Biogeochemical Research in the Shingobee River Headwaters Area, North-Central Minnesota. US Geological Survey WaterResources Investigations Report, 96-4215, pp. 3-10.

Norton, A.R., 1982. Quaternary geology of the Itasca-St. Croix Moraine interlobate area, north-central Minnesota. U.S. Geological Survey Hydrologic Investigations Atlas HA-278.

Northcote, T.G., Hall, K.J., 1983. Limnological contrasts and anomalies in two adjacent saline lakes. Hydrobiologia 105, 179-194.

Porter, S.C., Sauchyn, D.J., Delorme, L.D., 1999. The ostracode record from Harris Lake, southwestern Saskatchewan: 9200 years of local environmental change. Journal of Paleolimnology 21, 35-44.

Rosenberry, D.O., 1985. Factors contributing to the formation of transient water-table mounds on the outflow side of a seepage lake, Williams Lake, central Minnesota. MS Thesis, University of Minnesota, Minneapolis.

Rosenberry, D.O., Winter, T.C., Merk, D.A., Leavesley, G.H., Beaver, L.D., 1997. Hydrology of the Shingobee River headwaters area. In: Winter, T.C. (Ed.), Hydrological and Biogeochemical Research in the Shingobee River Headwaters Area, North-Central Minnesota. US Geological Survey Water-Resources Investigations Report, 964215, pp. 19-23.

Schwalb, A., Dean, W.E., 1998. Stable isotopes and sediments from Pickerel Lake, South Dakota, USA: a 12 ky record of environmental changes. Journal of Paleolimnology 20, 15-30.

Schwalb, A., Locke, S.M., Dean, W.E., 1995. Ostracode $\delta^{18} \mathrm{O}$ and $\delta^{13} \mathrm{C}$ evidence of Holocene environmental changes in the sediments of two Minnesota lakes. Journal of Paleolimnology 14, 281-296.

Seaburg, J.K., 1985. Geohydrologic interpretation of glacial geology near Williams Lake, Central Minnesota, with emphasis on lakegroundwater interaction. Master Thesis, University of Minnesota, $141 \mathrm{pp}$.

Siegel, D.I., Winter, T.C., 1980. Hydrologic setting of Williams Lake, Hubbard County, Minnesota. U.S. Geological Survey Open-File Report 80-703, 56pp.

Smith, A.J., 1993. Lacustrine ostracodes as hydrochemical indicators in lakes of the north-central United States. Journal of Paleolimnology $8,121-134$.

Smith, A.J., Donovan, J.J., Ito, E., Engstrom, D.R., 1997. Groundwater processes controlling a prairie lake's response to middle Holocene drought. Geology 25 (5), 391-394.

Sprowl, D.R., Banerjee, S.K. 1993. Geologic implications of the Elk Lake paleomagnetic record. In: Bradbury, J.P., Dean, W.E. (Eds.), Elk Lake, Minnesota: Evidence for Rapid Climate Change in the North-Central United States, Special Paper 276. Geological Society of America, Boulder, CO pp. 159-162.

Stevens, L.R., 1997. The stable-isotopic composition of sediment from two varved lakes: implications for climate change in Minnesota. Ph.D. Thesis, University of Minnesota, 286pp.
Stuiver, M., 1970. Oxygen and carbon isotope ratios of fresh-water carbonates as climatic indicators. Journal of Geophysical Research 75 (27), 5247-5257.

Talbot, M.R., 1990. A review of the palaeohydrological interpretation of carbon and oxygen isotopic ratios in primary lacustrine carbonates. Chemical Geology (Isotope Geoscience Section) 80, 261-279.

Teeri, J.A., Stowe, L.G., 1976. Climatic patterns and the distribution of $\mathrm{C}_{4}$ grasses in North America. Oecologia 23, 1-12.

Turpen, J.B., Angell, R.W., 1971. Aspects of moulting and calcification in the Ostracod Heterocypris. Biological Bulletin 140, 331-338.

Valero-Garcés, B.L., Kelts, K.R., 1995. A sedimentary facies model for perennial and meromictic saline lakes: Holocene medicine Lake Basin, South Dakota, USA. Journal of Paleolimnology 14, 123-149.

Valero-Garcés, B.L., Laird, K.R., Fritz, S.C, Kelts, K., Ito, E., Grimm, E., 1997. Holocene climate in the northern Great Plains inferred from sediment stratigraphy, stable isotopes, carbonate geochemistry, diatoms, and pollen at Moon Lake, North Dakota. Quaternary Research 48, 359-369.

Von Grafenstein, U., Erlenkeuser, H., Trimborn, P., 1999. Oxygen and carbon isotopes in modern fresh-water ostracod valves: assessing vital offsets and autoecological effects of interest for palaeoclimate studies. Palaeogeography, Palaeoclimatology, Palaeoecology 148, 133-152.

Watts, W.A., Bright, R.C., 1968. Pollen, seed, and mollusk analysis of a sediment core from Pickerel Lake, Northeastern South Dakota. Geological Society of America Bulletin 79, 855-876.

Webb III, T., Cushing, E.J., Wright Jr., H.E., 1983. Holocene Changes in the vegetation of the Midwest. In: Late-Quaternary Environments of the United States, Vol. 2, pp. 142-165.

Whitlock, C., Bartlein, P.J., Watts, W.A., 1993. Vegetation history of Elk Lake. In: Bradbury, J.P., Dean, W.E. (Eds.), Elk Lake, Minnesota: Evidence for Rapid Climate Change in the NorthCentral United States. Boulder, Colorado, Geological Society of America Special Paper, 276, pp. 251-274.

Winter, T.C., 1999. Relation of streams, lakes, and wetlands to groundwater flow systems. Hydrogeology Journal 7, 28-45.

Winter, T.C., Rosenberry, D.O., 1997. Physiographic and geologic characteristics of the Shingobee River headwaters area. In: Winter, T.C. (Ed.), Hydrological and Biogeochemical Research in the Shingobee River Headwaters Area, North-Central Minnesota. US Geological Survey Water-Resources Investigations Report, 964215, pp. 11-17.

Winter, T.C., Harvey, J.W., Franke, O.L., Alley, W.M., 1998. Ground water and surface water, a single resource. US Geological Survey Circular, 1139, 79pp.

Wright, H.E., 1967. A square-rod piston sampler for lake sediments. Journal of Sedimentary Petrology 37, 975-976.

Wright, H.E., 1976. The dynamic nature of Holocene vegetation-a problem in paleoclimatology, biogeography, and stratigraphic nomenclature. Quaternary Research 6, 581-596.

Xia, J., Ito, E., Engstrom, D.R., 1997a. Geochemistry of ostracode calcite: Part I. An experimental determination of oxygen isotope fractionation. Geochimica et Cosmochimica Acta 61, 377-382.

Xia, J., Ito, E., Engstrom, D.R., 1997b. Variation of stable-isotope and trace-element composition of lacustrine ostracodes from the northern Great Plains: effects of lake water chemistry and seasonal temperature variation. Geochimica et Cosmochimica Acta 61, 383-391.

Xia, J., Haskell, B.J., Engstrom, D.R., Ito, E., 1997c. Holocene climate reconstructions from tandem trace-element and stable-isotope composition of ostracodes from Coldwater Lake, North Dakota, USA. Journal of Paleolimnology 17, 85-100. 